ISSN 1112-9867

http://www.jfas.info

\title{
PREPARING STUDENTS FOR RESEARCH ACTIVITIES IN THE CONTEXT OF COMPETENCE-ORIENTED ENGINEERING EDUCATION
}

\author{
O. O. Gorshkova
}

From Federal State Budget Educational Institution of Higher Education, Industrial University of Tyumen, to only "Industrial University of Tyumen"

Published online: 08 August 2017

\begin{abstract}
The article presents the conceptual framework for preparing students for research activities in the context of competence-oriented engineering education that provide for a focus on the program-target education quality management system; incorporation of employers' requirements to the preparation of technical university graduates for research activities and provisions of occupational standards. Inquiry-based learning has been considered the basis for the establishment of the innovative didactics of a technical university that enables implementation of the requirements of educational standards of competitive graduates. Content of the innovative didactics of the technical university presented as a functional model fosters the creative development of students, their research capabilities and functional research skills as universal ways of interaction with the outside world. The elaborated and experimentally tested functional model of the establishment of technical university students' research competencies has been considered. This model provides for the creation of the development-promoting educational environment at the university in the course of theoretical, production and hands-on training, independent and research activities. These activities are performed using the elaborated practice-focused techniques, special-purpose forms and means of extracurricular activities; information technology, network educational resources; system of tasks, comprehensive, end-to-end research projects, interactive forms and methods; students' self-testing and self-evaluation in the process of training.
\end{abstract}

\footnotetext{
Author Correspondence, e-mail: author@gmail.com

doi: http://dx.doi.org/10.4314/jfas.v9i2s.853
} 
Keywords: engineering education, research competence, preparation for research activities, program-target management system, resource model.

\section{INTRODUCTION}

Transition to innovative economy, information technology development, design and outspread of complex man-machine systems and social engineering have resulted in quality changes of engineering activities and turned them into a comprehensive drive of society's technological transformation. This brings about a need for the competitive engineers willing to take an active part in innovative engineering processes, development of new ideas, settlement of research production tasks, able to think outside the box and make unconventional decisions oriented at future technologies [10]. Peculiarities of engineering activities that take into account special features of modern production bring about crucial changes in specialists' activities and, thus, the concept of their training. The "Concept of the development of research and innovative activities at Russian universities" says that new skilled workers have to be oriented at future technology, study of problem situations and finding technically adequate solutions. Quality of engineers is one of the key factors behind the state's competitive power, the basis for its technological and economic independence. According to the National Doctrine of Engineering Education of the Russian Federation [15], its main direction of development is the special arrangement of students' work as part of comprehensive multidiscipline practice-oriented teams, engagement in active creative work, creation of practice-oriented modes of study, assurance of participation in research and educational activities.

Peculiarities of engineering activities, integration of a competence approach into engineering education, HE FSES (higher education federal state educational standards), adoption of occupational standards result in a brand new approach to students' training at universities and bring about a need for an adaptive system that ensures graduates' training in the context of occupational mobility and competitive power, their development as creative, social and humanistic personalities.

Study purpose: elaboration and introduction of the concept of preparing students for research activities in the context of competence-oriented engineering education.

\section{Study methods}

Theoretical (study, analysis and synthesis of educational, social, engineering, economic reference literature on the matter in hand; review of the study subject; educational process simulation; summation of study results); empirical (review of normative documents, 
observation, interviews, testing, self-evaluation, review of documents, study of deliverables, educational design); experimental (educational experiment, methods of statistical analysis of results).

\section{Study results and their discussion}

The performance evaluation of the current system of students' research training has shown that most students have a low level of research competence maturity. Review of findings has proved that students show no interest in research activities and know very little about the research element in engineer's work.

Analysis of the scientific support of preparing technical university students for research activities has revealed a number of earlier elaborated concepts, models and technologies presented in thesis studies. Research motivation matters have been examined in the papers by O.O. Nenasheva [13], A.L. Mazaletskaya [12] that have proven the efficiency of the crosscurriculum integration of scientific knowledge in project research activities; assurance of the emotional and value component; fostering student's stable focus on scientific knowledge. I.Yu. Danilova [9] has established that research motivation promotes the atmosphere that encourages independent search for solutions to problems; comfortable psychological situation and research drive.

Some researchers (E.A. Grebennikova [5], A.A. Gubaidullin [7], M.A. Osintseva [16], I.A. Tkacheva [21]) have studied possibilities of preparing students for research activities by using research knowledge, turning it into problems; encouraging out-of-the-box approaches and solutions; using computer technology. N.I. Naumkin [14] has studied preparation for research activities in terms of immersion into engineering creativity (training in the environment of academic competitions); use of knowledge to solve research problems, experimental vocationally-orientated tasks, course design.

According to I.A. Yanyuk [24], technical university students' research competence may be effectively promoted by fostering a favorable environment at the university so that students could perceive the professional activity model and find their professional identity. D.R. Salyamova [18] who has studied the matters of raising research performance has concluded that a special focus should be on the development of co-operation between the state, scientific circles and academies, promoting conditions for the attraction and retention of highly-qualified staff at universities.

Authors $[14 ; 19]$ of studies of the establishment of research skills have revealed the required conditions: teaching process saturation with creative situations, its creative arrangement; introduction of research activity elements; transition from reproductive to productive 
activities.

Some researchers $[6 ; 14 ; 20]$ studied the capabilities of the competence approach in the course of preparing for research activities. They have found out that students' readiness for educational and research activities is possible subject to introduction of special courses, promotion of incentives for research activities, use of active methods, information technologies; modular learning.

Review of the works has shown that the researchers focus on important aspects of the preparation for research activities and pay special attention to the content of engineering education, technology component of generating the research competence in students. However, the existing works do not adequately reflect the conceptual idea of preparing students for research activities, which requires special organizational measures and has a significant potential to improve the quality of vocational education. Research activities are not (and may not be) considered as the basis for the development of general cultural and professional competencies for the implementation of the requirements of HE FSES. Thus, preparation for research activities has not been studied in terms of the basis for building innovative didactics of the technical university. The researchers have ignored changes in the education quality management system, promotion of the development-promoting educational environment of the university. No close relationship between the university and employers and their participation in preparing students for research activities has been identified.

We have revealed the modern production trends caused by the retransformation of the industrial society into post-industrial: changes in functional and value orientations of labor; integration processes in production and modern science; informational support of human activities, intellectualization of production. The trends interact and make up a complex dynamic set of requirements that form the image of a specialist capable of full-fledged personal and professional self-actualization.

Historical analysis of the problem of preparing students for research activities has shown that the knowledge-based approach, which is still used at technical universities and which is oriented at mastering currently used technologies and state of the art implemented in conventional subject-centered forms does not meet the requirements of the post-industrial society. Training of the modern engineers capable of generating ideas, ready for research activities and able to ensure innovative breakthroughs in hi-tech industries shall be based on the cross- and multidisciplinary principle [23, p. 13]. Engineering education in Russia is at the stage of development when preparation for research activities requires justified improvement of the learning process in the technical university. 
Expert poll of employers (JSC Surgutneftegaz, JSC Gazprom Neft, Schlumberger, Baker Hughes, CJSC LUKOIL, LLC Gazprom Transgaz Surgut, LLC Gazprom Pererabotka, LLC NOVATEK, etc. - a total of 128 executives) conducted with an aim to study their satisfaction with the quality of graduates' training has enabled identification of the main requirements to preparation for research activities of the technical university graduate. They include: ability to study technical devices, technology and processes in order to upgrade and improve plant performance; ability to process information for the purposes of analysis and evaluation of production conditions, diagnosis, process control, taking corrective measures in case of deviation from set-up parameters; ability to make the best decisions in emergency, analyze them; ability to settle research tasks in normal and abnormal situations; assess emerging risks, make decisions subject to the set of production factors; ability to use mathematical tools, application software products, facilities, network resources; activity in teamwork when developing the projects oriented at the improvement of performance indicators; adequate activity analysis; self-testing, activity in professional self-development, self-improvement and self-affirmation [2, p. 76].

Study of the foreign experience $[25 ; 26 ; 27 ; 28 ; 29 ; 31 ; 32]$ has enabled identification of a number of the provisions that are expedient to be considered when preparing students of the technical university for research activities: addition of the special disciplines targeted at the preparation for research activities into the curriculum; stepwise introduction of methods to settle research tasks, use of heuristic approaches, idea generation methods; development of industrial engineering skills, aesthetical development of students; implementation of group and individual research projects as part of involvement of students in research activities; close co-operation with production enterprises; replacement of competitiveness with co-operation; free access to information resources and software; maintenance of portfolio, ethical upbringing.

HE FSES as the means of innovative transformation of engineering education promotes its focus on students, determines obligatory elements of preparing technical university students for research activities. However, we have determined a number of the provisions ignored in the standards, but required to obtain competitive graduates: compulsory conformity of $\mathrm{HE}$ FSES to occupational standards; accounting of integrative processes; addition of the special courses oriented at the implementation of projects, end-to-end research tasks; work with basic enterprises, entering into contracts for students' target preparation; introduction into the learning process of the virtual laboratory research that ensures access to unique and closed processes; technology, equipment. We have also found out that the competencies provided in 
HE FSES do not suffice to promote the students' research competence, due to which it has been proposed to expand their set with special competencies: insight into the essence and meaning of research activities in the general structure of engineering activities, its importance for professional self-actualization with regard to aesthetical and ethical standards; having a system of research value benchmarks, motivation for research; ability to make effective use of generalized target bases of research activities during interdisciplinary research; creativity in engineering based on own self-consciousness [2, p. 25].

Analysis of occupational standards of the engineering activity structure; set of general cultural and professional competencies has revealed that the research nature shows itself as the leading component of engineer's activities, labor functions identified in combination with required skills have a research component (focus) and determine the need for preparing technical university students for research activities.

We view engineer's research activities as the process of dedicated and active human interaction with a real or simulated object targeted at the new knowledge acquisition in line with intellectual needs of the person and society.

Based on existing scientific provisions on the activity structure $[8 ; 11 ; 17]$ and considering components of an ideal model of a psychological activity system [22] that allows to reduce various activity forms to a certain abstract model that reflects the components common to any type of activity and their connections, the following components of engineer's research activities have been identified: object (production processes, technology, technical elements, etc.), subject (properties of technical objects under study and new knowledge acquisition process), causes (demand for self-actualization and self-improvement, cognition drive, responsibility for the result, need for recognition and self-affirmation, material wealth drive), objective (improvement of production technical and economic indicators, assurance of its continuity), actions (organizational, operational, control and judgmental), result (elimination of technical failures, faults, improvement of production technical and economic indicators, introduction of new technology, technical innovations, inventions).

Determination of the engineer's research activity structure permits to give special priority to the didactics of settling research tasks. As a result of the review of FSES, occupational standards, we have identified the following main research tasks subject to employers' requirements:

1. review of information on operation of technical devices and process flow;

2. conduct of experimental studies of objects (technical devices and processes) choosing the best methods; 
3. statistical processing of experimental results, preparation of reports (description of studies conducted, data preparation for making up reports, overviews and other documents);

4. original data collection and submission for object model building (based on fundamental science achievements); design documentation related to the improvement of processes, technology, equipment; identification of the methods to eliminate (prevent) negative effects;

5. process design calculations, assessment of various impacts on production processes (using application software products); assessment of economic benefit of decisions made;

6. presentation of results as design, technology, detail documents; participation in the preparation of design and research solutions.

We view the problem of developing the technical university students' research competence from the perspective of the competence approach, which interacts with conventional approaches (axiological, value-motivational, synergetic, integrative, pragmatist, contextual) thus being strategic and introducing fundamental changes to the learning process that are expressed in an enhanced practical and instrumental focus of engineering education.

Thus, there is an evident need and good timing for the creation and introduction of the holistic concept of preparing technical university students for research activities in the context of competence-oriented engineering education that defines inquiry-based learning as the basis for building innovative didactics of the technical university as part of the developing national system of qualifications that enables implementation of the requirements of HE FSES to the establishment of a set of professional, special and general cultural competencies.

In the concept, we use the program-target education quality management system at universities, which allows to: set socially justified and realistic goals, namely, development of the students' research competence; set up a task group (representatives of universities, basic enterprises); elaborate the research training program that presents stages of the process of development of the students' research competence, technology and methods in use, possibility to control and adjust innovations, stepwise monitoring of results; guarantee required support: personnel, material and technical, information, methodological, etc. Shift to the programtarget education quality management system has contributed to the establishment of the development-promoting educational environment at the university targeted at the development of the students' research competence in the course of theoretical, production and hands-on training, independent and research activities.

We view the development-promoting educational environment as the competence-oriented space that fosters the conditions targeted at the assurance of optimal parameters of technical 
university educational activities in the course of preparing students for research activities, namely, assurance of the target, conceptual, operational, resultative and resource aspects.

The development-promoting educational environment of the technical university comprises the following structural components (Figure 1): space-subject component (architectural and aesthetic organization of the educational process; symbolic space (university's marks and traditions, etc.)); conceptual component (functional model as the content of the concept); organizational component: staff resources, managerial resources, communications (partnership relations between the teacher and students based on the adoption of common objectives; harmonization of interests of all educational process participants: management, task group, teachers, students, representatives of enterprises; promotion of the productive activity atmosphere), organizational conditions. Staff resources provide for setting up of a team of like-minded fellows pursuing a common objective by way of coordinating activities of structural units of the university (chair, practical training department, training directorate) and individual teachers; advanced vocational training of university employees.

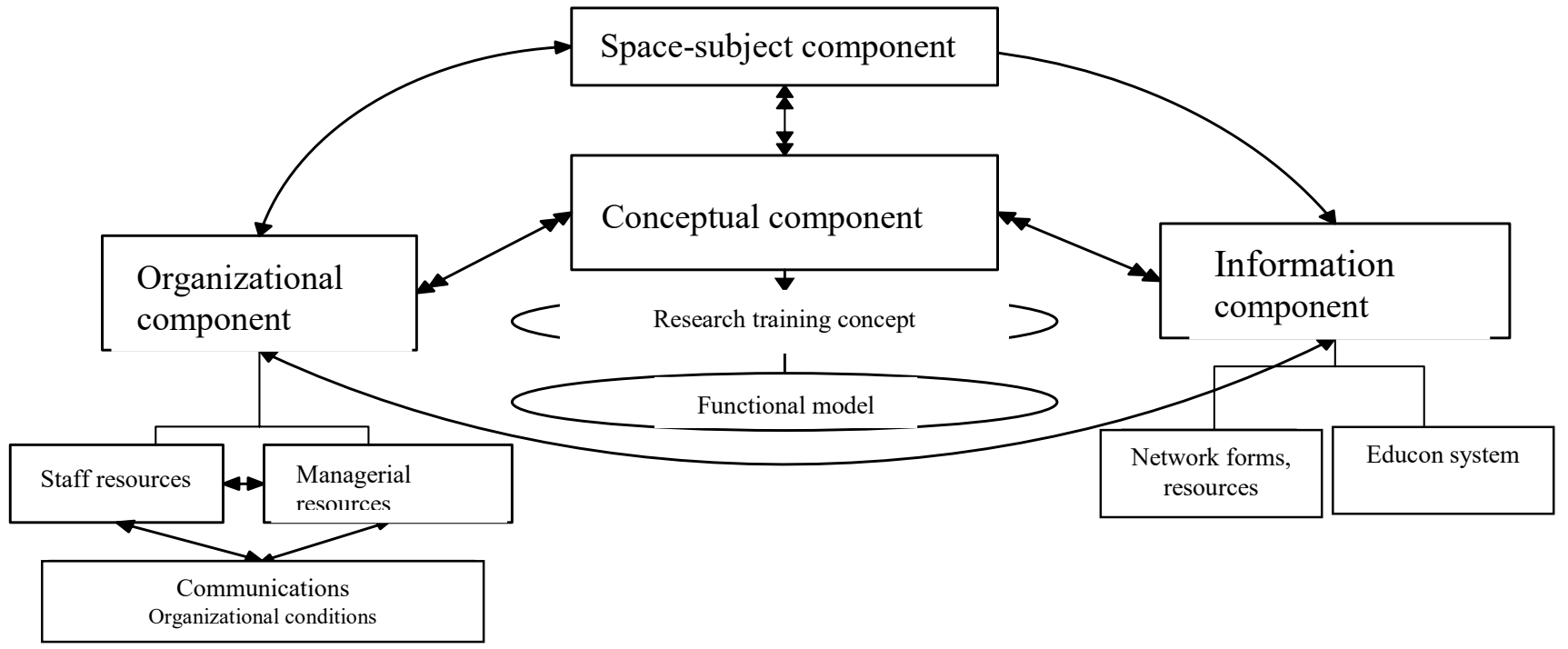

Fig.1. Structure of the university's development-promoting educational environment

The information component provides for networking, use of network educational resources, implementation of Educon electronic system of learning process support intended to foster the development of the infrastructure of the common educational information space. The arrangement of the technical university's development-promoting educational environment comprised several steps: 1. encouraging students to prepare for research activities; 2. arrangement of the interaction and synergy of all the subjects sharing the environment 
space; 3. arrangement of students' self-regulation.

Establishment of the development-promoting educational environment in the technical university is an essential condition to settle the task of the creation of innovative didactics of the technical university targeted at preparing students for research activities subject to employers' requirements to the training level of the graduates that have an individual and productive style of engineering activities. This ensures the following:

- arrangement of the interaction and synergy of all the subjects sharing the environment space (university teachers, employees, representatives of basic enterprises, students);

- teaching and research integration at al stages of the educational process;

- transformation of the education content, development of new and improvement of existing methodological support; review of organizational and technology fundamentals of the educational process (elaboration of practice-oriented methods, special forms and means of extracurricular activities; information technology; systems of buildings, projects, conventional and interactive forms and methods);

- establishment of the system of partnership with universities, research organizations, enterprises. The "resource model" of the network form of the educational program implementation is used, according to which integrated co-operation agreements are made with basic enterprises. This enables the well-aimed allocation of graduates, involvement of enterprise representatives in the student training process (elaboration and adjustment of the main educational programs; practice programs, pool of evaluation tools, research tasks, participation in the defense of research works, term projects, student's research); practical training; field laboratory and practical works; teachers' traineeship teacher; monitoring of demand for graduates, analysis of their performance, etc.);

- students' self-regulation, self-generation (assurance of students' personal and professional development, involvement in the education quality co-management subject to their self-organization in the course of creativity promotion (increased share of independent work, abandonment of reproductive methods) [4, p. 60].

The concept is of interdisciplinary nature being a part of the integral content of occupational training and basis of the process for the promotion of the students' research competence. The structure of preparing technical university students for research activities is provided in figure 2 . 


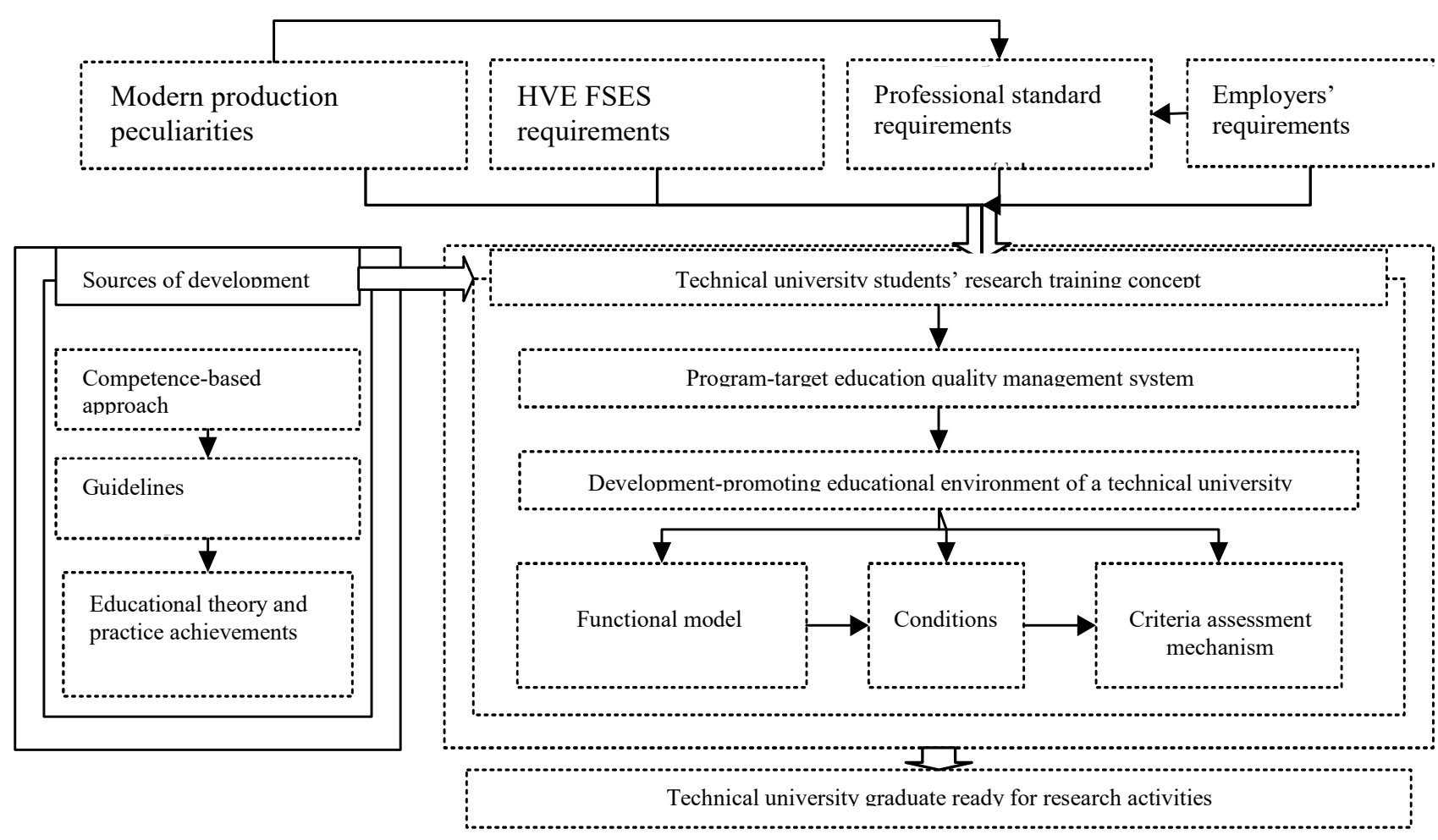

Fig.2. Structure of preparing technical university students for research activities

The following principles are basic for the concept implementation: program-target approach to management - systematic monitoring of students' readiness for research activities; establishment of the university's development-promoting educational environment that provides for the motivation, co-operation and synergy of all the subjects sharing the environment space; learning and research integration at all stages of educational process; transformation of the engineering education content, development of practice-oriented methods, special forms and means of students' activities; consideration of employers' requirements and occupational standards based on the system of partnership with base enterprises; students' involvement in the education quality co-management subject to their self-organization in the course of inquiry-based learning; criteria and diagnostic ability of results.

The concept content is implemented in the functional model of preparing students for research activities, which forms the basis of the innovative didactics of the technical university that comprises: target; motivational, conceptual; operational and pragmatist; control-result components (Figure 2). 


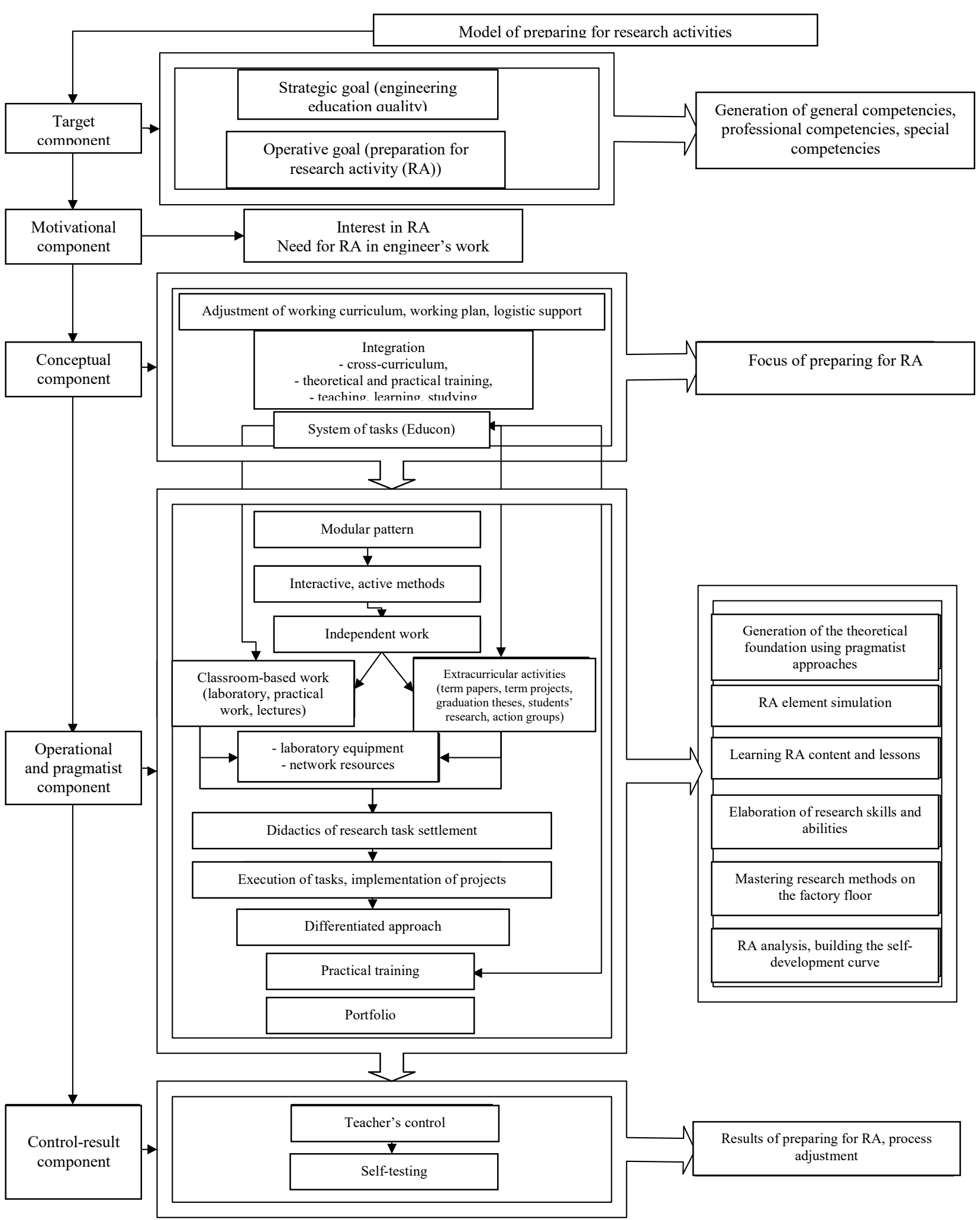

Fig.3. Functional model of preparing technical university students for research activities (RA) $[3$, p. 174]. 
When the conceptual component was elaborated:

- $\quad$ education content was structured;

- cross- and intersubject integration of disciplines ("Physics" and "Electrical Engineering"; "Electrical Engineering"; and "Oil and Gas Equipment"; "Engineering Mechanics" and "Resistance of Materials"; "Geology" and "Oil/Gas Field Development", "Petrophysics", etc.) was ensured. This brought together teachers of different subject units, helped approve the content of working programs, lectures, laboratory and practical works;

- the sequence and methods of solution of research tasks and end-to-end research assignments were coordinated. Students mastered research activity techniques in a gradual and orderly manner, gained individual research experience, mastered the target basis of actions. Educational guidance provided for the arrangement of communication, pragmatist cooperation, students' educational support, mindset instilling stable motivation for research activities was created;

- possibilities offered in the disciplines of the basic part of the curriculum were defined and possible changes were made into their content (special practical courses "Methods of Solution of Engineer's Non-Standard Research Tasks", "Research Culture”, "Mathematical Statistics Methods in Engineering Research", "Creation in the Engineer's Occupation", "Heuristic Research Methods", etc. were introduced);

- changes were introduced to the variable part of the curriculum, the following special courses were elaborated: "Research Method Fundamentals", "Professional SelfDetermination", "Bases of Engineer's Research Activities" that, in addition to basic disciplines, contributed to a shift of focus to the learning process as a process of productive cognition and mastering research actions;

- tasks (elaborated jointly with enterprise representatives) targeted at the solution of practical production problems were included in the practical training; methodological support was elaborated;

- working programs were modified as per HE FSES; content of the competencies to be generated was specified; intersubject communications were analyzed; list of laboratory, practical, independent works with their procedures (with a focus on active and interactive methods) were described in detail, competencies were determined; ratings were presented.

The content was determined with regard to employers' requirements, occupational standards of preparing students for research activities; main occupational educational programs were jointly elaborated and adjusted; tasks as part of classroom and extracurricular activities were compiled. 
The system of motivators contributed to the conscious adoption and implementation of research activity objectives, harmonization of interests of educational process participants; establishment of partnership relations between the teacher and students based on the adoption of common objectives. Attention was given to the understanding of the research activity experience (post-practical training group discussions, meetings with enterprise executives, role and business games, project implementation, etc. with a focus on the social and personal meaning, activity objectives and results) specially arranged as part of the learning process in order to get students engaged in self-cognition, self-observation, self- and peer evaluation.

We have used the modular learning process building scheme that provides for the study of the discipline material in the course of learning and research activities, rating control (rating indicators). This helped students master general principles of building concepts and conclusions, make abstract generalizations, encouraged independence, ensured self-paced module mastering.

The use of interactive technologies contributes to the promotion of students' cognitive and research activities and ensures a high problematic level. The following forms are used: discussions (dialogue, discussion, case study, etc.); games: (didactic, creative games, including business (managerial), role, organizational and pragmatist games); trainings; interactive pragmatist ("collision of ideas", "expansion of sentences", "coming close to real engineering activities", "tampering method"). Students' creativity is promoted through gaining new experience from its theoretical understanding by way of the application of problems in the solution process. The most effective are problem-based lectures (visualization lecture, two-men lecture, lecture with intended errors), inversion and analytical type lectures, dispute lectures.

The possibility to present the material as a problem is used when analyzing various concepts for the solution of the same problem, when considering different approaches to a particular research problem; when reasons for a gap between the production theory and practice are identified; when students' theoretical knowledge is coupled with its application conditions in actual production or in non-standard conditions, etc.

The students' research competence is promoted by the work methods that come closer to actual research activities and that imitate actual professional situations. Laboratory and practical works are performed based on the principle of co-creativity, joint research activities of students and teachers; classes are built by the context type [1]. Students can feel that the tasks performed are getting increasingly complicated (tasks of levels 1, 2, 3 that have different rating scores are proposed), and have positive emotions from their success experience. 
Initially, laboratory works are performed using the ready reference maps that specify task techniques (Material Science, Geology, Engineering Mechanics, etc.). At the next stage, students are offered partially filled reference maps. They complete the work on their own and present results (Oil and Gas Chemistry, Operations Geology, Electrical Engineering, etc.). As the work with reference maps progresses, their content becomes collapsed and students independently search for the required information (Petrophysics, Drilling Complications and Accidents, Oil Field Fluid Mechanics, Enhanced Oil Recovery, etc.). This arrangement of classes contributes to the promotion of the generalized arrangement of research activities in students.

The research competence is also promoted by field and virtual laboratory and practical works at production bases of basic enterprises. The elaboration and use of virtual works, presentations, tours improve the teaching process performance thanks to the enhanced virtual presence at enterprises, laboratories, unique process showcases, remote observation of as-is flowing processes. When laboratory and practical tasks are performed, students develop research skills, which is also driven by the use of capabilities of networking with representatives of basic enterprises; electronic (network) educational resources that allow to observe the processes under study, hypothesize, collect data for study, simulate objects and processes, find the best solutions. The model uses Educon electronic system of learning process support (creation and placement of electronic teaching materials, virtual laboratory and practical works; presentations, task systems for classroom and extracurricular activities, students' evaluation (self-testing, control or evaluation control); access to professionally relevant information (lectures, presentations), electronic library systems, public educational resources; possibility of communication between teachers and students (consultations, reviews).

A special focus is on the task system. Classroom (laboratory and practical works), extracurricular (field laboratory works, independent work) activities, networking are envisaged for the task execution. Attention is also given to the didactics of the solution of research tasks with task assignment and assessment of given conditions; definition of result requirements; research planning (search for ideas), selection of research methods and determination of the structure of actions, verification of results, their evaluation [30]. Students' research actions are formed by proposing tasks of various types that get increasingly complicated. There is a possibility of each student's involvement in the active cognitive research process, practical application of the knowledge obtained and clear understanding of where, how and for what objectives it may be used, which generates their 
pragmatist position. Tasks are classified by the nature of cognitive activities: unit 1 information receptive; unit 2 - base projective; unit 3 -project-empirical; unit 4 -research.

Project implementation is one of the most effective tools of the research competence development. Projects of the initial (basic) level are used as part of project activities during years 1-2 of study. These projects help master the basic knowledge and develop general cultural and professional competencies.

The enhanced project level (students' research, term projects, graduation thesis (GT)) requires information and new data search, analysis and arrangement, longer time for preparation; thus, they are conducted on an extracurricular basis. To implement such projects, action groups (in line with the chair specialization) are set at chairs. Results of creative task performance and project implementation are summed up at conferences, workshops, round-table discussions together with representatives of basic enterprises. It is important to use comprehensive research projects, end-to-end research tasks when preparing theses and GT (paper topics are tied in with chair research directions and demands of a particular production site). GT accumulates the research experience gained by students, which affects its performance quality.

Novelty in arranging all types of practical training is ensured by the research nature of students' activities; task individualization, focus on the solution of problems of a particular production site; use of end-to-end tasks; joint development and coordination of tasks, practical training programs with enterprise representatives; public defense of practical training reports, discussion of results.

Practical training is conducted using the tasks targeted at the solution of actual production problems, which helps students master research methods. The practical training arrangement (year 1) provides for students' mastering of empirical research methods (observation, interview, summing up results, record keeping, etc.); analysis and comparison operations. The first production training (year 2) comprises as follows: study of the research engineering experience of enterprise employees, elaboration and implementation of measures to implement the practical training program, solution of actual research tasks. The second production practice (year 3) provides for the students' specially arranged work with the research subject, which enables the shift to the performance of research tasks in the production environment.

We have proved that there may not be a single level of the students' research competence development, which is explained by different capabilities, individual peculiarities and levels of training. This requires an individual approach; the most talented students are assigned 
consultants and "individual pathways" are elaborated. Students take an active part in the elaboration of group and individual projects, contests and conferences [30].

An important moment is the creation of a portfolio comprising works that represent the history of student's development through the presentation of various activity results, which is his/her self-presentation tool and which fosters self-organization, self-development and selfconsciousness.

The control-result component provides for teacher's control over the process of the students' research competence development and its correction if required as well as students' selftesting. Self-testing functions get stronger, students become more conscious and willed and their research activities get more meaningful. Control is exercised using the following methods: testing (Educon system), polling, audit, defense of tasks and projects, regular observation of students' activities. The following is ensured for the effective self-analysis, self-testing and self-evaluation of the process and results of research activities by students: review of research activity performance criteria; control and self-testing methods and techniques (polling, testing, ranking, self-evaluation, observation); development of own action analysis and evaluation skills; access to rating figures. The model control and evaluation has the following peculiarities: variety of forms of intermediate and current control (Educon system); student's choice of a final report form based on activity results; use of educational diagnosis that helps predict possible deviations and make corrections.

We have identified the following components of readiness for research activities: cognitive, personal, pragmatist that we use as criteria to evaluate technical university students' readiness for research activities.

Cognitive - defines the level of insight into the conceptual framework, ability to use the theoretical foundation obtained in the course of research activities.

Personal - motives and value system of a personality, students' self-consciousness in the course of research activities.

Pragmatist - defines the level of mastering research methods and ability to use mastered methods and knowledge accumulated in practice.

All the readiness criteria are assessed by a four-level scale. The high level comprises the top level typical of the most talented students. Combined evaluation helped consider maturity variation of each criterion.

Functional model integration performance evaluation is monitored by changes in the maturity of the students' research competence level (Table 1). A total of 1,520 persons were engaged in experimental activities, including 1,390 students and 130 teachers. 
Table 1. Research competence development changes, $\%$

\begin{tabular}{|c|c|c|c|c|c|c|c|c|}
\hline \multirow{2}{*}{$\begin{array}{l}\text { Personal component } \\
\text { Motivational }\end{array}$} & \multicolumn{2}{|c|}{ 2012-2013 ac. y } & \multicolumn{2}{|c|}{ 2013-2014 ac. y } & \multicolumn{2}{|c|}{ 2014-2015 ac. y } & \multicolumn{2}{|c|}{ 2015-2016 ac. y } \\
\hline & Ex. & Cont. & Ex. & Cont. & Ex. & Cont. & Ex. & Cont. \\
\hline Top & 0 & 0 & 3 & 0 & 3 & 1 & 3 & 1 \\
\hline High & 0 & 0 & 27 & 2 & 37 & 3 & 45 & 9 \\
\hline Medium & 5 & 2 & 25 & 10 & 28 & 15 & 40 & 26 \\
\hline Low & 53 & 38 & 30 & 58 & 29 & 61 & 10 & 54 \\
\hline Zero & 42 & 60 & 15 & 30 & 3 & 20 & 2 & 10 \\
\hline \multicolumn{9}{|l|}{ Reflexive } \\
\hline Top & 0 & 0 & 3 & 0 & 3 & 1 & 3 & 1 \\
\hline High & 0 & 0 & 27 & 2 & 37 & 3 & 45 & 9 \\
\hline Medium & 5 & 2 & 25 & 10 & 28 & 15 & 40 & 26 \\
\hline Low & 53 & 38 & 30 & 58 & 29 & 61 & 10 & 54 \\
\hline Zero & 42 & 60 & 15 & 30 & 3 & 20 & 2 & 10 \\
\hline \multicolumn{9}{|l|}{ Cognitive element } \\
\hline Top & 0 & 0 & 3 & 0 & 3 & 1 & 3 & 1 \\
\hline High & 1 & 0 & 25 & 4 & 38 & 7 & 50 & 19 \\
\hline Medium & 4 & 2 & 25 & 18 & 32 & 25 & 40 & 38 \\
\hline Low & 52 & 36 & 30 & 48 & 24 & 50 & 7 & 40 \\
\hline Zero & 43 & 62 & 17 & 30 & 3 & 17 & 0 & 2 \\
\hline \multicolumn{9}{|c|}{ Pragmatist component } \\
\hline Top & 0 & 0 & 3 & 0 & 3 & 1 & 3 & 1 \\
\hline High & 0 & 0 & 26 & 1 & 42 & 1 & 49 & 9 \\
\hline Medium & 5 & 2 & 27 & 20 & 35 & 30 & 40 & 43 \\
\hline Low & 55 & 28 & 29 & 39 & 15 & 48 & 7 & 44 \\
\hline Zero & 40 & 70 & 15 & 40 & 5 & 20 & 1 & 3 \\
\hline
\end{tabular}

Changes in experimental groups are stable for all the components. Positive developments in control groups mean that the level of students' readiness for research activity improves with the accumulation of experience in learning and research activities as part of conventional teaching, but the process is not active enough. The model performance was also acknowledged in the course of benchmarking of performance results of the graduates of the 
year 2016 (experimental groups) and performance results of the graduates of the year 2012 (Table 2).

Table 2. Level of graduates' research competence, $\%$

\begin{tabular}{|l|c|c|c|c|c|c|}
\hline \multirow{2}{*}{ Levels } & \multicolumn{2}{|c|}{ personal } & \multicolumn{2}{c|}{ cognitive } & \multicolumn{2}{c|}{ pragmatist } \\
\cline { 2 - 7 } & 2012 & 2016 & 2012 & 2016 & 2012 & 2016 \\
\hline Top & 1 & 3 & 1 & 3 & 1 & 3 \\
\hline High & 4 & 45 & 12 & 50 & 4 & 49 \\
\hline Medium & 16 & 40 & 36 & 40 & 36 & 40 \\
\hline Low & 66 & 10 & 47 & 7 & 47 & 7 \\
\hline Zero & 13 & 2 & 4 & 0 & 12 & 1 \\
\hline$\chi^{2}$ & \multicolumn{2}{|c|}{121} & \multicolumn{3}{|c|}{69,7} & \multicolumn{2}{c}{100,8} \\
\hline
\end{tabular}

Results have been verified by way of a statistical analysis-based check using mathematical statistics criteria: Peirce chi-square. With the implementation of the functional model, the students from experimental groups have revealed statistically significant considerable changes in the maturity level of all research competence components.

\section{CONCLUSION}

The modern stage of engineering education development is characterized by the predominance of the problem of research training of technical university students that requires rethinking of engineering education tasks and objectives and establishment of the conceptual framework of educational activity at technical universities.

Results of the experiments conducted to approve the key points of the concept implemented through the functional model have confirmed the assumption, according to which its integration contributes to the research competence development in technical university students, their creative development, motivation, value-based attitude to research, willingness to take an active part in innovative engineering processes, ability to develop new ideas, solve research production tasks and make out-of-the-box decisions.

The theoretical relevance of the study lies in the following facts:

- Theory and methodology of vocational education have been enriched with insights into the essence of the process of students' research readiness development in the context of competence-oriented education as the basis for engineering training that enables the 
development of general cultural, professional and a number of special competencies for training the specialists that have individual and productive style of engineering activities;

- conceptual framework for preparing students for research activities in the context of competence-oriented engineering education has been elaborated; this framework provides for a focus on the program-target education quality management system; incorporation of employers' requirements to the preparation of technical university graduates for research activities and provisions of occupational standards; definition of inquiry-based learning as the basis for building innovative didactics of the technical university that enables implementation of the requirements of HE FSES to the development of competitive graduates;

- content of the innovative didactics of the technical university presented as a functional model has been determined; this model fosters the creative development of students, their research capabilities and functional research skills as universal ways of interaction with the outside world.

- the functional model of preparing technical university students' for research activities has been elaborated and experimentally tested. This model provides for the creation of the development-promoting educational environment at the university intended to ensure readiness for research activities in the course of theoretical, production and hands-on training, independent and research activities performed using: elaborated practice-focused techniques, special-purpose forms and means of extracurricular activities; information technology, network educational resources; system of tasks, comprehensive, end-to-end research projects, interactive forms and methods; students' self-testing and self-evaluation in the process of training;

Thus, the work develops the theory of vocational education, in particular, as related to students' professional preparation for research activities and consideration of engineers' training in terms of the competence paradigm. The work examines the idea of the modern engineer's professional self-actualization.

The practical relevance of the study lies in the following facts:

- the concept of preparing technical university students for research activities that meets modern society and production development requirements brought by the author to the level of state-of-the-practice may be used in the arrangement of the teaching process at technical universities to improve the quality of engineering education; 
- the elaborated and approved mode of preparing technical university students for research activities may be applied in basic and extended engineering education in order to improve the competition of graduates;

- recommendations as to the arrangement of preparing students for research activities for the teaching staff of technical universities may be used in the advanced training system of technical university teachers.

\section{REFERENCES}

[1] Verbitskiy A.A. Invariants of professionalism: formation challenges [Invarianty professionalizma: problemy formirovaniya] / Verbitskiy A.A., Ilyazov M.D. Moscow: Logos, 2011. P. 288.

[2] Gorshkova O.O. Preparing students for research activities in the context of competenceoriented engineering education [Podgotovka studentov $\mathrm{k}$ issledovatelskoy deyatelnosti $\mathrm{v}$ kontekste kompetentnostno-orientirovannogo inzhenernogo obrazovaniya]. Extended abstract from the thesis of Doctor habil. in Education: 13.00.08. Moscow: FIRO, 2016. P. 59.

[3] Gorshkova O.O. Preparing students for research activities in the context of competenceoriented engineering education [Podgotovka studentov $\mathrm{k}$ issledovatelskoy deyatelnosti $\mathrm{v}$ kontekste kompetentnostno-orientirovannogo inzhenernogo obrazovaniya]. Thesis of Doctor habil. in Education: 13.00.08 / Gorshkova O.O. Moscow: 2016. P. 394.

[4] Gorshkova O.O. Framework for professional preparation of students of engineering institutions for research activities [Kontseptualnye osnovy professionalnoy podgotovki studentov inzhenernykh vuzov k professionalnoy deyatelnosti] / Alma mater (Bulletin of higher education institutions). Moscow: 2015. No. 1. P. 59-62.

[5] Grebennikova E.A. Building of creative activity in students while studying general mathematical disciplines. Evidence from engineering higher education institutions [Formirovanie tvorcheskoy aktivnosti studentov pri izuchenii obschematematicheskikh distsiplin: Na primere inzhenernykh vuzov]. Thesis of Ph.D. in Education: 13.00.08 / Grebennikova Elena Aleksandrovna. Volgograd: 2006. P. 170.

[6] Grosheva E.P. Preparing students of technical higher education institutions for innovation activities while teaching engineering creativity and patenting [Podgotovka studentov tekhnicheskikh vuzov k innovatsionnoy deyatelnosti pri obuchenii inzhenernomu tvorchestvu i petentovedeniyu]. Thesis of Ph.D. in Education: 13.00.02 / Grosheva Elena Petrovna. Saransk: 2010. P. 216. 
[7] Gubaidullin A.A. Building of research competence in students in the context of projectbased learning [Formirovanie issledovatelskoy kompetentnosti studentov $\mathrm{v}$ usloviyakh proyektnogo obucheniya]. Thesis of Ph.D. in Education: 13.00.01 / Gubaidullin Artur Albertovich. Kazan, 2011. P. 235.

[8] Davydov V.V. Challenges of developmental teaching: theoretical and experimental research [Problemy razvivayushchego obucheniya: opyt teoreticheskogo i eksperimentalnogo issledovaniya]. Moscow: Akademiya, 2004. P. 283. P. 375.

[9] Danilova I.Yu. Multi-level model of organization of scientific research of students as the means of ensuring quality of education in higher education institutions [Mnogourovnevaya model organizatsii nauchno-issledovatelskoy raboty studentov kak sredstvo obespecheniya kachestva obrazovaniya v vuze]. Thesis of Ph.D. in Education: 13.00.08 / Danilova Irina Yurievna. Moscow, 2010. P. 172.

[10] Concept for the long-term socio-economic development of the Russian Federation until 2020 [Kontseptsiya dolgosrochnogo sotsialno-ekonomicheskogo razvitiya Rossiyskoy Federatsii do 2020 goda] [Electronic resource] // Interregional public organization in support of Information for All program. Available at: http://www.ifap.ru/ofdocs/rus/rus006.pdf.

[11] Leontyev A.N. Activity. Consciousness. Personality [Deyatelnost. Soznaniye. Lichnost]. Moscow: Politizdat, 1977. P. 304.

[12] Mazaletskaya A.L. Dynamics of motivation of scientific research activity at the stages of professional development [Dinamika motivatsii nauchno-issledovatelskoy deyatelnosti na etapakh professionalizatsii]. Thesis of Ph.D. in Education: 19.00.03 / Mazaletskaya Anna Leonidovna. Yaroslavl, 2011. P. 217.

[13] Nenasheva O.O. Scientific research activity as a factor for development of axiological capacities of a student [Nauchno-issledovatelskaya deyatelnost kak faktor razvitiya aksiologicheskogo potentsiala lichnosti studenta]. Thesis of Ph.D. in Education: 13.00.01 / Nenasheva Olga Olegovna. Orenburg, 2010. P. 221.

[14] Naumkin N.I. Methodological system for the formation of capabilities in students of technical higher education institutions for innovation engineering activity in the process of teaching of general technical disciplines [Metodicheskaya sistema formirovaniya u studentov tekhnicheskikh vuzov sposobnostey $\mathrm{k}$ innovatsionnoy inzhenernoy deyatelnosti $\mathrm{v}$ protsesse obucheniya obshchetekhnicheskim distsiplinam]. Thesis of Doctor habil. of Education: 13.00.02 / Naumkin Nikolay Ivanovich. Saransk, 2009. P. 499. 
[15] National doctrine of engineering education in Russia [Natsionalnaya doktrina inzhenernogo obrazovaniya $\mathrm{v}$ Rossiyskoy Federatsii] [Electronic resource]. Available at: http://aeer.cctpu.edu.ru/winn/doctrine/doctrine 4.phtml.

[16] Osintseva M.A. Organizing the research activity of future engineers in the process of teaching of mathematics using information and communication technologies [Organizatsiya issledovatelskoy deyatelnosti budushchikh inzhenerov pri obuchenii matematike $\mathrm{s}$ ispolzovaniem informatsionno-kommunikatsionnykh tekhnologiy]. Thesis of Ph.D. in Education: 13.00.02 / Osintseva Marina Aleksandrovna. Tyumen, 2009. P. 206.

[17] Petrovskiy A.V. Personality: phenomenon of subjectivity [Lichnost: fenomen subyektnosti]. Rostov-on-Don: Fenix, 1993. P. 147.

[18] Salyamova D.R. Encouragement of the development of scientific research activity in higher education institutions [Stimulirovanie razvitiya nauchno-issledovatelskoy deyatelnosti v vysshem uchebnom zavedenii]. Thesis of Ph.D. in Economics: 08.00.05 / Salyamova Dinara Ravilevna. Moscow, 2009. P. 210.

[19] Terekhina O.S. Formation of research skills in students of engineering higher education institutions [Formirovanie issledovatelskikh umeniy studentov inzhenernykh vuzov]. These of Ph.D. in Education: 13.00.08 / Terekhina Olga Sergeevna. Nizhniy Novgorod, 2010. P. 181.

[20] Timofeeva E.M. Formation of the preparedness of the future metallurgical engineer for continuous educational and research activity [Formirovanie gotovnosti budushchego inzhenera-metallurga k nepreryvnoy uchebno-issledovatelskoy deyatelnosti]. These of Ph.D. in Education: 13.00.08 / Timofeeva Elena Mikhaylovna. Belgorod, 2009. P. 227.

[21] Tkacheva I.A. Development of research activity in student of technical specialties in the process of teaching of natural science disciplines [Razvitie issledovatelskoy deyatelnosti studentov tekhnicheskikh spetsialnostey $\mathrm{v}$ protsesse izucheniya estestvennonauchnykh distsiplin]. Thesis of Ph.D. in Education: 13.00.08 / Tkacheva Irina Aleksandrovna. Moscow: 2009. P. 236.

[22] Shadrikov V.D. Activity and abilities [Deyatelnost I sposobnosti]. Moscow: Logos, 1994. P. 315.

[23] Chuchalin A.I. Modernization of the economy and improvement of quality of engineering education [Modernizatsiya ekonomiki i povyshenie kachestva inzhenernogo obrazpvaniya] / Alma Mater. Moscow: 2011. No. 11. P. 111-17.

[24] Yanyuk I.A. Formation of research competence in students of engineering higher education institutions [Formirovanie issledovatelskoy kompetentnosti studentov 
tekhnicheskikh vuzov]. Thesis of Ph.D. in Education: 13.00.08 / Yanyuk Ivan Aleksandrovich. Shuya, 2010: P. 214.

[25] Arden P. It's Not How Good You Are, It's How Good You Want To Be / P. Arden. Phaidon Press, 2003. P. 128.

[26] Birch P. Imagination Engineering: A Toolkit for Business Creativity. Financial Times Prentice Hall, 1999. P. 217.

[27] Baxter M. Product Design. Practical Methods for Systematic Development of New Products. London: Chapman\&Hall, 2003. P. 303.

[28] Baumol W.J. The Free-Market Innovation Machine: Analyzing the Growth Miracle of Capitalism. Princeton University Press, 2004. P. 336.

[29] Daemmrich A.A. R\&D Meets M\&A: Proceedings of the 2003 Conference on Innovation and Creativity in Chemical R\&D // Chemical Heritage Foundation, 2004. P. 110.

[30] Gorshkova O.O. Network Educational Resources in the Research Student Training Revista // Revista ESPACIOS , Vol. 38 (N 25), Year 2017.

[31] Kogan M. Lifelong learning in the UK // European Journal of Education. Blackwell Publishers Ltd., 2005. V.35. N.35. P. 34-45.

[32] TUNING Educational Structures in Europe. Reference Points for the Design and Delivery of Degree Programmes in Education. Bilbao (Spain): University of Deusto, 2009. P. 108.

\section{How to cite this article:}

Gorshkova O O. Preparing students for research activities in the context of competenceoriented engineering education. J. Fundam. Appl. Sci., 2017, 9(2S), 1445-1467. 